\title{
主題I-2 再弁置換の諸問題
}

一生体弁を中心姃—

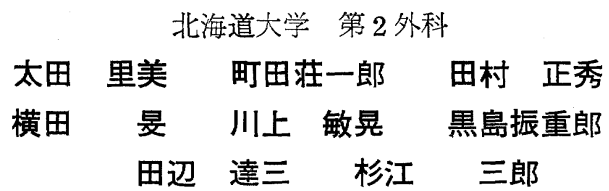

われわれの後天性心疾患に対する弁置換症例虫，62 例 であり，AVR は 21 例（生体弁 5 例, 人工弁 16 例) M VR は 38 例（生体弁 16 例, 人工弁 22 例), 両弁置換 3 例（生体弁 1 二使用）である。この5ち再弁置換を意図 して行なわれた手術は 8 例で, 置換部位は大動脈弁 1 例, 僧帽弁 7 例, 初回弁は生体弁 5 例，人工弁 3 例であ る.

\section{再弁手術の原因（表 1)}

生体弁では症例 1 は 6 年 7 力月経過の同種 BPL 弁で, 2 弁尖に亀裂を生じた弁不全, 症例 $2 \sim 4$ の 3 例は異種 ethanol 弁であり, 置換後 7 力月〜 5 年 1 力月間に一様 に弁尖の菲薄化，弾性低下をきたし，さらに症例により 穿孔，亀裂，反転，離脱などを生じた弁不全例である。 症例 5 は同種 vial l graft であるが， 3 年 9 力月後まで 弁尖は competent であったが, perivaluvular leak を生 じた。
人工弁では 2 例は SAM 弁, Starr-Edwards Model 6500 に塞栓頻発した例であり, 症例 8 は大動脈炎症候 群例であり弁置換後 3 力月にて炎症の活動化が再燃し, detatchmentを生じた例であった。

\section{成績（表 1$)$}

これら 8 例に対し Bjork-Shiley 弁 2 コ, 異種グルタ ール弁 2 コ, 異種ホルマリン弁 1 コ, 同種抗生剂弁 2 コ を用いて 6 例洅弁置換を行なったが，他の 2 例は弁置 換に至らなかった，症例 3 は肺静脈血の逆流が強く，弁 置換が不能であった例であり, 症例 8 は離開部の再縫合 にて修復可能と判断し，置換を見合わせた例であった。 これらの成績は生存 4 例, 死亡 4 例であり, 死因は低心 拍出症 候群 2 例, 出血 2 例であったが, 症例 1 は出血 control のため bypass を再開, 灌流中に心の action が 弱くなった例である。

このような LOS を防止するためには再弁置換に踏み

表 1 再弁手術症例

\begin{tabular}{|c|c|c|c|c|c|c|c|c|c|c|}
\hline & 例 症 & 年齢 & 性 & 弁 処 理 法 & 観察期間 & $\begin{array}{l}\text { NYHA } \\
\text { 分 類 }\end{array}$ & 弁 所 見 & 手 術 法 & 転帰 & 因 \\
\hline 1 & & 20 & 우 & 同種 BPL & 6 年 7 力月 & IV & 2 弁尖に亀裂 & Bjork-Shiley 弁 & 死 & 出 血 \\
\hline 2 & & 24 & 우 & 異種エタノール & 5 年 1 力月 & IV & 弁尜菲薄化穿孔, & "l & 死 & 低心拍出症候群 \\
\hline 3 & & 47 & $\hat{\sigma}$ & 異種エタノール & 1 年 8 力月 & IV & 㕕尜弾性低下, 弁 & $\begin{array}{l}\text { 左房溢血のため } \\
\text { 具換不能 }\end{array}$ & 死 & 低心拍出症候群 \\
\hline 4 & & 22 & 우 & 異種エタノール & 7 力月 & III & $\begin{array}{l}\text { 弁尜菲薄化, 弁尖 } \\
\text { 離脱, 迢逆流 }\end{array}$ & $\begin{array}{l}\text { 異種ホルマリン } \\
\text { 茾 }\end{array}$ & 生 & \\
\hline 5 & & 23 & 우 & 同種抗生剈 & 3 年 9 力月 & II & 周辺逆流 & $\begin{array}{l}\text { 異種グルタール } \\
\text { 茾 }\end{array}$ & 生 & \\
\hline 6 & & 43 & 今 & SAM & 3 年 9 力月 & II & $\begin{array}{l}\text { 弁口周辺, 可動部 } \\
\text { に血栓 }\end{array}$ & 同種抗生剈弁 & 生 & \\
\hline 7 & & 44 & 우 & $\begin{array}{l}\text { Starr-Edwards } \\
\text { Disc }(6500)\end{array}$ & 6 年 3 力月 & II & $\begin{array}{l}\text { 弁口周辺, struts } \\
\text { K血栓 }\end{array}$ & $\begin{array}{l}\text { 異種グルタール } \\
\text { 茾. }\end{array}$ & 死 & 出 血 \\
\hline 8 & & 26 & 5 & jörk-Shiley & 1 年 & III & $\begin{array}{l}\text { 弁離開, 大動脈瘤 } \\
\text { 形成 }\end{array}$ & $\begin{array}{l}\text { 離開部再縫合メ } \\
\text { ショ包絡 }\end{array}$ & 生 & \\
\hline
\end{tabular}


表 2 再弁手術前の検査成績

\begin{tabular}{|c|c|c|c|c|c|c|c|c|c|c|c|c|}
\hline 症 & 初 回 弁 & 過 & $\begin{array}{l}\text { 再弁手術の } \\
\text { 囷 }\end{array}$ & $\begin{array}{l}\text { CTR } \\
(\%)\end{array}$ & $\begin{array}{c}\text { 逆流 音 } \\
\text { Levine }\end{array}$ & $\underset{(\mathrm{mV})}{\mathrm{RV}_{5}+\mathrm{SV}_{1}}$ & $\begin{array}{c}\text { 心 指 数 } \\
(\mathrm{L} / \mathrm{min} \\
\left.\quad / \mathrm{m}^{2}\right)\end{array}$ & $\begin{array}{l}\text { PAst } \\
\text { (平均压 } \\
\text { mmHg) }\end{array}$ & $\begin{array}{c}\text { PAW } \\
(11)\end{array}$ & $\begin{array}{l}\text { 逆流波 } \\
(\mathrm{mmHg})\end{array}$ & $\mid \begin{array}{c}\text { 心造影 } \\
\left(\begin{array}{c}\text { Sel- } \\
\text { lors })\end{array} \mid\right.\end{array}$ & 転帰 \\
\hline 1 & 同種 BPL & 6 年 7 力月 & 弁 不 全 & 62.3 & $4 / 6$ & 5.0 & 4.10 & 28 & 28 & 40 & III & 死 \\
\hline 2 & 異種エタノール & 5 年 1 力月 & 弁 不 全 & 60 & $4 / 6$ & 3.2 & 4.20 & $3 j$ & 28 & 3) & III & 死 \\
\hline 3 & 異種エタノール & 1 年 8 力月 & 弁 不 全 & 62 & $4 / 6$ & 5.2 & & 42 & 22 & 45 & III & 死 \\
\hline 4 & 異種エタノール & 7 力月 & 弁 不 全 & 62 & $4 / 6$ & 7.0 & & 40 & 32 & 46 & III & 生 \\
\hline 5 & 同種抗生剂 & 3 年 9 力月 & 周辺逆流 & 68 & $2 / 6$ & 4.7 & 3.81 & 26 & 22 & 32 & III & 生 \\
\hline 6 & SAM & 3 年 8 力月 & 脳塞栓頼発 & 53 & $0 / 6$ & 1.2 & 4.27 & 16 & 9 & - & - & 生 \\
\hline 7 & $\begin{array}{l}\text { Starr-Edwards } \\
(6500)\end{array}$ & 6 年 3 力月 & 脳塞栓頻発 & 63.4 & $0 / 6$ & 4.6 & 4.42 & 18 & 12 & - & - & 死 \\
\hline 8 & Bjork-Shiley & 1 年 & 弁 離 脱 & 62.3 & $3 / 6$ & 9.0 & 4.40 & 26 & 17 & $\begin{array}{r}\text { Ao 质 } \\
160 / 50\end{array}$ & III & 生 \\
\hline
\end{tabular}

きる時期が問題で, 初回弁置換後の経過を検討してみる 之, 生体弁の弁不全例（症例 $1 \sim 4$ ） では一旦逆流が起 り出すと, 決して remissionすることなく漸増的に増悪 し, その速度も増してくる. detatchment 症例（症例 5，8）では増悪傾向は徐々ではあるが，これも好転の兆 しをみせない，CTRにつき経過を追ってみると，逆流 を呈した全例で，一旦低下した CTR が再上昇を示し， ついには $60 \%$ をこえる。故に，逆流音 Levin 3 度， CTR 再上昇をみたなら, 直ちに心カテを行ない肺動脈 (楔入) 圧の上昇, 逆流波, Angio にて Sellors 2 度以 上では，とくに生体弁では躊らよなく再弁置換に踏みき るべきである(表 2 )。

\section{手技上の問題点}

出血例は左房壁, および左房内よりの冠動脈回施枝の 損傷であった。癒着剥離は最小限に止めるのが有利であ り，回施枝は初回手術時よりは弁輪縁に近ずいており， 注意が必要である. 再弁置換に至らなかった 1 例は肺動 静脈圧の上昇が持続した例であり, excess return from bronchial flow の状態であった.この場合 core cooling, 循環遮断などの処置が必要であったと思われ，またこの ような状態になる前に手術に踏みきるべきであったと反 省している。大動脈炎症候群例では縫合不全が起り易 く, pledget の使用, 壁外へ糸を通すなどの注意は当然 であるが，長い battress 縫合なども考虑すべきであり， 時には Bentall 手術も必要となろう。

\section{生体弁の再弁置換の原因}

生体弁では塞栓, thrombosed valve は殆んぞなく, 心内膜炎も弁尖の破綻を招くから，結局再弁置換の原因
となるものは組織変性などによる弁破綻と perivaluvular leak とになる. 弁破綻では生体弁の処理法拉よび frame の flexibility がもっとも大きな影響力をもち，われわれ の同種 BPL 弁の 8 例はいずれも組織変性, 心内膜炎に より弁不全をきたした。これに比し同種抗生剂弁 (viable graft)では1例に perivaluvular leakをきたしたが， competency を保って打り，他の 1 例子5 年 8 力月に亘 り経過良好である。異種 ethanol 弁 8 例では一様に弁尖 の菲薄化, 弾性低下をきたし，弁不全に至ったが，glutaraldehyde 処理の Hancock 弁 2 例の成績はよい。

これらを組織学的に比較してみると，もっとも耐久性 に影響のある膠原線維, 弾性線維などの線維構造の保持 は同種 viable graft および異種 glutaraldehyde 弁で良 好であり, 前者では 3 年 9 力月経過例でも線維芽細胞が 弁尖表面拈よび弁尖内にみられる. gluraldehyde 処置弁 では生物学的活性が除かれ，2 年 2 力月経過例でもほ注 置換前と同様な線維構造が保たれていた。これに対し BPL, ethanol 処理弁では細胞性, 宿主よりの修復機転 も極めてそしく, 線維構造の変性萎縮, 断裂がみられ た。

\section{結語}

生体弁の再弁置換の対象は大部分が弁不全であり，弁 不全を来し易い処理法の弁は今後使用すべきでなく，置 換例に扣いて逆流音の増大傾向, CTR の再上昇がみら れたら心力テ，心血管造影にて弁不全を証明し，弁不全 は漸増的に増悪することを考慮して，早期に再弁置換に 踏みきるべきである。しかし時間的余裕は人工弁よりは 遙かにあると思われる。 